\title{
Feeding of anchovy Engraulis encrasicolus larvae in the northwestern Adriatic Sea in response to changing hydrobiological conditions
}

\author{
D. V. P. Conway ${ }^{1, *}$, S. H. Coombs ${ }^{1}$, C. Smith ${ }^{2}$ \\ ${ }^{1}$ Natural Environment Research Council, Centre for Coastal and Marine Sciences, Plymouth Marine Laboratory, \\ Prospect Place, Plymouth, Devon PL1 3DH, United Kingdom \\ ${ }^{2}$ School of Biological Sciences, Queen Mary and Westfield College, University of London, London E1 4NS, United Kingdom
}

\begin{abstract}
Results from depth integrated and vertically stratified plankton sampling in the northwestern Adriatic Sea were used for comparison of gut contents of larvae of European anchovy Engraulis encrasicolus with composition and concentration of potential prey in the plankton. Sampling was carried out over a grid of stations both before and after a period of increased wind mixing to investigate changes in food availability and larval feeding success. All larvae had empty guts soon after dusk, indicating daytime feeding and rapid gut clearance. With increasing larval length there was a greater percentage of specimens with empty guts, despite suitable food being available in the plankton for these larger larvae; this suggests differential gut evacuation during sampling - possibly related to the degree of gut development. Larval diet was principally the various developmental stages of copepods, especially calanoid and cyclopoid nauplii, which were preferentially selected by larvae, whereas selection was against harpacticoid nauplii. Lamellibranch larvae and Peridinium spp. were generally abundant in the plankton, but were only present in the gut contents in any number when the preferred dietary organisms were present in the plankton at low concentrations. The number of food organisms in the gut contents increased with concentration of the preferred food organisms in the plankton up to a limit of $\sim 50$ organisms $\mathrm{l}^{-1}$. Within the upper $18 \mathrm{~m}$ of the water column, there was a reduction in the proportion of larvae with food in their guts with increasing depth, irrespective of the vertical profile of food concentration. Following a period of wind mixing the composition of the plankton changed. This was reflected in the diet of anchovy larvae, which altered in parallel. There was also an overall $41 \%$ decrease in concentration of the preferred food particles of larvae in the plankton following the period of wind mixing, but larvae were still able to maintain their food intake. These results show that anchovy larvae can successfully adapt their diet to a changing prey field and suggest that in the conditions observed in the northern Adriatic, quite radical changes in the feeding environment were probably insufficient to affect overall larval mortality.
\end{abstract}

KEY WORDS: Anchovy larvae - Diet - Feeding success - Food selection - Wind mixing

\section{INTRODUCTION}

The recruitment strength of many fish stocks is thought to be determined within the first year of life (Bradford \& Cabana 1997), and while much research has been directed towards establishing the contribution to mortality from variation in feeding success during the early larval stages, the connection is still con-

·E-mail:dvpc@ccms.ac.uk troversial (Leggett \& Deblois 1994). One problem in establishing this link has been that the results of laboratory studies on food requirements of larval fish are often at variance with field observations (Mackenzie et al. 1990). This discrepancy may be a reflection of a combination of inadequate attempts to replicate field conditions experimentally and field sampling techniques which do not accurately resolve the larval prey field. Regardless of the problems of reconciling studies on the relationship between feeding and recruitment, there is continuing evidence from field studies of a link 
between feeding success, availability of preferred food and the proportion of fish larvae which are in poor condition (Anderson 1994, Theilacker et al. 1996). Additionally, it has been shown in laboratory experiments that the mortality of larval fish can decrease with increasing food availability (Gotceitas et al. 1996) and that the size range of available food can determine growth rate and cohort size structure (Geffen 1996). Because mortality rates generally decrease with increase in larval size (Pepin \& Myers 1991), feeding efficiency (quantity and assimilable content of food organisms, balanced against energy expended capturing them), in parallel with predation (Bailey \& Houde 1989), must still be considered as a potentially prime biological factor in modifying recruitment.

A physical factor which has not been integral in most experimental studies, but which is considered to have a substantial effect on feeding success in larval fish, is degree of turbulence, due primarily to wind mixing, although this may have positive or negative effects (Dower et al. 1997). Moderate turbulence in the water column may act to enhance feeding success in larvae through changes in encounter rates between larvae and their prey, although this has to be balanced against the possibly increased energetic costs associated with feeding in turbulent waters. Conversely, turbulence may disrupt established thermal structure and plankton concentrations (Lagadeuc et al. 1997), resulting in a reduction in larval feeding success (Lasker 1975), decreased growth rates (Maillet \& Checkley 1991) and increased mortality rates (Peterman \& Bradford 1987).

Data for the present study were obtained on a cruise carried out in June/July 1996 in the northwestern Adri- atic Sea in the region of the River Po outflow. This formed part of a joint programme between the Plymouth Marine Laboratory (PML) and the Istituto Centrale per la Ricerca scientifica e tecnologica Applicata al Mare (ICRAM), the overall aim of which was to measure the nutritional condition and survival of larval European anchovy Engraulis encrasicolus in response to changes in environmental conditions following a period of wind mixing (Coombs et al. 1997, McFadzen $\&$ Franceschini 1997).

The shallow northern Adriatic is vulnerable to periods of strong wind mixing, even during the summer months (July and August) of peak spawning of anchovy (Zore-Armanda \& Gačić 1987, Regner 1996). An extensive sampling programme was carried out which gave broad-scale information on both hydrography and plankton distribution and was coupled with high resolution sampling at selected sites in order to determine the vertical distribution of anchovy larvae and their food resources. These data were utilised to give a detailed account of the diet of larval anchovy and to assess changes in diet and feeding success in response to food availability when stable hydrographic conditions were interrupted by a period of wind mixing.

\section{METHODS}

Sampling for anchovy larvae and associated plankton and concurrent environmental observations were carried out from the research vessel N/O 'Thetis' in the northwestern Adriatic Sea (Fig. 1) between 16 June and 12 July 1996.

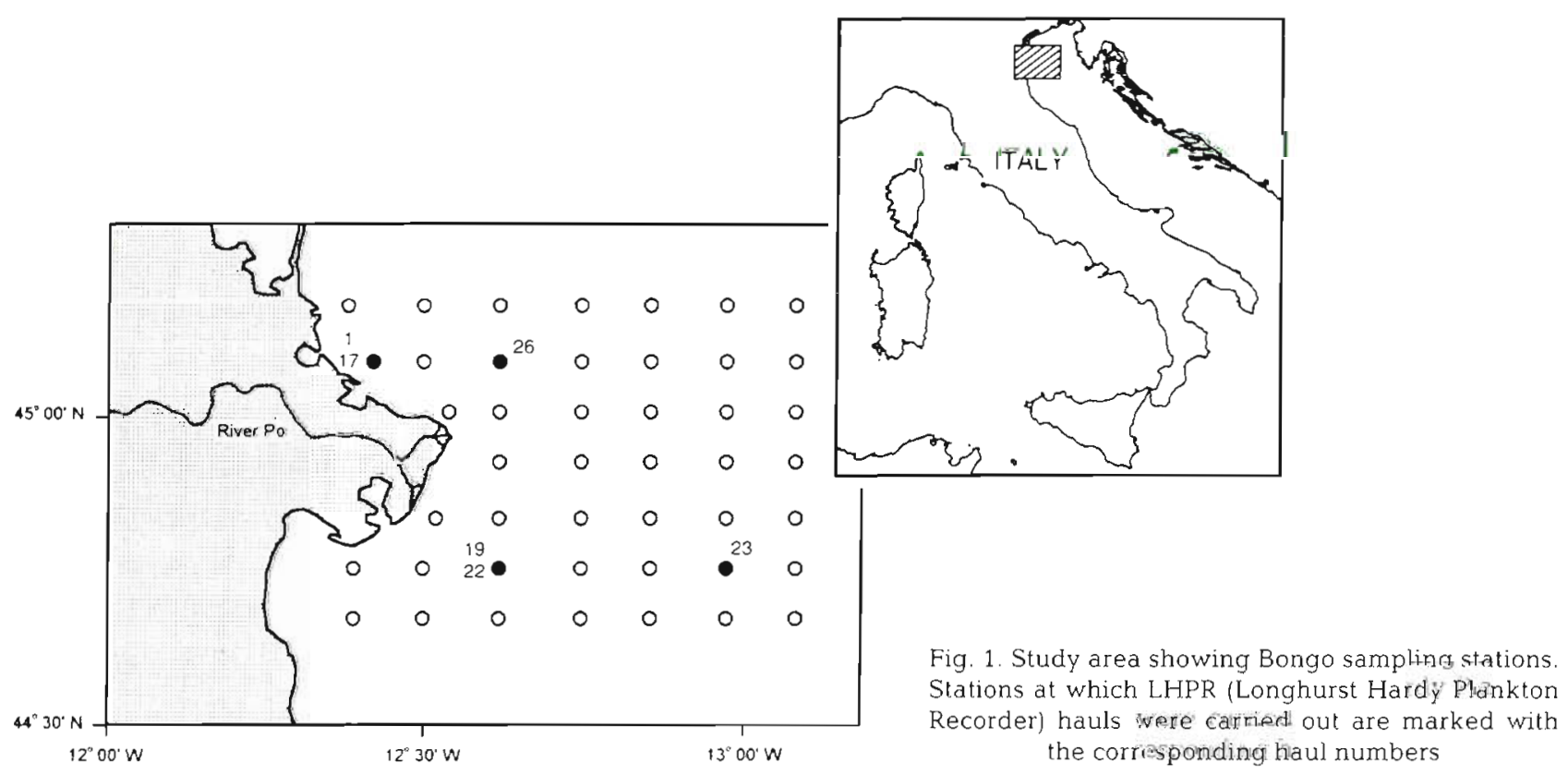


Table 1. Bongo net sampling grid information for anchovy larvae 2.4 to $10.9 \mathrm{~mm}$ in length

\begin{tabular}{|cccccc|}
\hline Grid & $\begin{array}{c}\text { Date } \\
(1996)\end{array}$ & $\begin{array}{c}\text { Samples } \\
\text { containing } \\
\text { larvae }\end{array}$ & $\begin{array}{c}\text { Samples } \\
\text { containing } \\
\text { feeding larvae }\end{array}$ & $\begin{array}{c}\text { Total } \\
\text { larvae } \\
\text { examined }\end{array}$ & $\begin{array}{c}\text { Larvae } \\
\text { containing } \\
\text { food }\end{array}$ \\
\hline 1 & $\begin{array}{c}\text { 16-18 Jun } \\
2-4 \text { Jul }\end{array}$ & 41 & 33 & 1011 & 326 \\
2 & 44 & 28 & 840 & 176 \\
\hline
\end{tabular}

Table 2. Dimensions and dry weight conversion factors for food organisms taken by anchovy larvae 2.4 to $10.9 \mathrm{~mm}$ in length

\begin{tabular}{|lccc|}
\hline Organisms & $\begin{array}{c}\text { Mean length } \\
(\mu \mathrm{m})\end{array}$ & $\begin{array}{c}\text { Mean width } \\
(\mu \mathrm{m})\end{array}$ & $\begin{array}{c}\text { Weight conversion } \\
\text { factor }(\mu \mathrm{g})\end{array}$ \\
\hline Peridinium spp. & 74 & 37 & $0.10^{\mathrm{a}}$ \\
Copepod eggs & 73 & 73 & 0.10 \\
Calanoid nauplii & 172 & 68 & 0.27 \\
Cyclopoid nauplii & 109 & 52 & 0.20 \\
Harpacticoid nauplii & 145 & 87 & 0.24 \\
Oithona spp. & 218 & 115 & 0.34 \\
Other copepods & 350 & 138 & 0.65 \\
Lamellibranch larvae & 74 & 64 & $0.17^{\mathrm{a}}$ \\
& & & \\
astimated from nauplii dimensions & \\
\hline
\end{tabular}

Grid sampling. General features of the diet of anchovy larvae were studied from samples taken on 2 Bongo net sampling grids of 45 stations at a spacing of 5 nautical miles (Fig. 1). The first Bongo grid was sampled from $12: 00 \mathrm{~h}$ local time (UTC $+2 \mathrm{~h}$ ) on 16 June to $06: 00 \mathrm{~h}$ on 18 June 1996 ; following an interval of $14 \mathrm{~d}$, the second grid was sampled from $12: 00 \mathrm{~h}$ on 2 July to $06: 00$ h on 4 July 1996 . On both grids, sampling was carried out during both day and night. The coarse mesh $(280 \mu \mathrm{m})$ Bongo sampler was $30 \mathrm{~cm}$ in diameter; attached below it was a $9 \mathrm{~cm}$ diameter fine mesh $(53 \mu \mathrm{m})$ system. Both Bongo net systems were fitted with flowmeters to allow standardisation of the catch to unit volume filtered. The nets were towed at 2 knots from the surface to $-2 \mathrm{~m}$ above the sea bed in a double oblique haul. Values for real-time monitoring of sampler depth trajectory, together with sensor readings for flow, temperature and salinity, were obtained using an electronic sensor package mounted above the nets. Following each haul the plankton samples were preserved in $4 \%$ borax-buffered, fresh water formaldehyde solution ( $\mathrm{pH} 8.2$ ).

Larvae for feeding studies were subsequently sorted from the $280 \mu \mathrm{m}$ samples. The term 'larvae' has been used generally here to refer to all specimens posthatch. Whenever sufficient numbers of larvae were available, the complete digestive tracts of a minimum of 25 undamaged larvae were examined from each sta- tion of the 2 grids (Table 1). Larvae were measured (standard length) then the complete digestive tract was removed. Terminology for the regions of the digestive tract follows O'Connell (1976). The thin walled fore-gut is transparent and any food organisms within it could be identified and counted without dissection. The thicker walled mid-and short hind-gut were opened with dissecting needles in a petri dish containing water and examined under a binocular microscope. Sufficient larvae were obtained for analysis of results for specimens between 2.4 and $10.9 \mathrm{~mm}$ in length, which were separated into $1 \mathrm{~mm}$ length categories. Measurements taken make no allowance for shrinkage due to handling and preservation, but for clupeoids shrinkage is typically between 5 and $10 \%$ (Fox 1996).

Gut contents were identified to the lowest taxonomic level and counted. Because of the wide species range of copepod nauplii found in this region, these could only be identified to their Order, e.g. calanoid, cyclopoid or harpacticoid. Measurements of the size of food organisms were made for all measurable items. Dimensions measured were the total length and maximum width for copepod nauplii and Peridinium spp., cephalothorax length (not including the posterior reduced segment in Oithona spp.) and maximum width for copepods, maximum shell width and depth for lamellibranch larvae and diameter for copepod eggs. Using the observed mean dimensions, numbers of food organisms were converted to approximate dry weights (Table 2) utilising values from Hay et al. (1988) and equations from Thompson \& Harrop (1991).

The $53 \mu \mathrm{m}$ Bongo net samples were subsequently sieved through a $20 \mu \mathrm{m}$ mesh, rinsed with fresh water to remove the formaldehyde and transferred to fresh water in a $300 \mathrm{ml}$ graduated flask. Using a Stempel pipette, subsamples to provide approximately 150 of the organisms established from gut content analysis as the preferred dietary items of anchovy larvae were extracted and counted for estimates of regional food abundance. The counts of copepods were restricted to those $<275 \mu \mathrm{m}$ in cephalothorax width, this being the maximum width of the copepods measured in the diet.

Vertical distribution sampling. Longhurst Hardy Plankton Recorder (LHPR; Williams et al, 1983) hauls were taken at selected stations (Fig. 1) in order to study the vertical distributions of anchovy larvae and their potential food, and hence food selection by larvae at different prey concentrations down the water column. A double net LHPR system was used, this consisting of a coarse mesh net system of $280 \mu \mathrm{m}$ or $500 \mu \mathrm{m}$ mesh aperture (selected according to the ambient plankton 
Table 3. Sampling information for anchovy larvae from Longhurst Hardy Plankton Recorder (LHPR) hauls for samples with $>10$ anchovy larvae 2.4 to $6.9 \mathrm{~mm}$ in length

\begin{tabular}{|lcccccc|}
\hline $\begin{array}{l}\text { Haul } \\
\text { no. }\end{array}$ & $\begin{array}{c}\text { Date } \\
\text { (1996) }\end{array}$ & $\begin{array}{c}\text { Time } \\
\text { (local) } \\
\text { (h) }\end{array}$ & $\begin{array}{c}\text { Maximum } \\
\text { depth } \\
\text { sampled (m) }\end{array}$ & $\begin{array}{c}\text { No. of } \\
\text { samples }\end{array}$ & $\begin{array}{c}\text { Total } \\
\text { larvae } \\
\text { examined }\end{array}$ & $\begin{array}{c}\text { Larvae } \\
\text { with } \\
\text { food }\end{array}$ \\
\hline 1 & 21 Jun & $11: 30$ & 20 & 9 & 283 & 122 \\
17 & 7 Jul & $13: 30$ & 18 & 3 & 110 & 99 \\
19 & $9 \mathrm{Jul}$ & $14: 50$ & 26 & 6 & 225 & 93 \\
22 & 10 Jul & $10: 30$ & 28 & 2 & 32 & 15 \\
23 & 10 Jul & $15: 45$ & 36 & 1 & 22 & 10 \\
26 & 11 Jul & $16: 36$ & 26 & 7 & 125 & 48 \\
\hline
\end{tabular}

concentration) for collection of the larvae and a separate $53 \mu \mathrm{m}$ net fine mesh system for collection of the food organisms. The LHPR was towed obliquely at around 3.5 knots from the surface to $\sim 1 \mathrm{~m}$ above the sea bed, simultaneously collecting coarse and fine mesh samples at a sampling interval of $1 \mathrm{~min}$, with a vertical sample resolution of approximately $2 \mathrm{~m}$ depth. The coarse net filtered approximately $14 \mathrm{~m}^{3}$ of water for each sample, while the fine mesh filtered approximately $200 \mathrm{l}$. Following each haul, samples were preserved in $4 \%$ borax-buffered, fresh water formaldehyde solution ( $\mathrm{pH}$ 8.2). Values for real-time monitoring of depth and flow, together with profiles of temperature and salinity, were obtained on each haul via cored cable transmission of data from an electronic package mounted on the sampler frame. Anchovy larvae were subsequently sorted from the coarse mesh samples and analysed for gut contents in the same way as for specimens from the Bongo samples, sufficient larvae for analysis being available on 6 of the LHPR hauls (Fig. 1, Table 3). The $53 \mu \mathrm{m}$ zooplankton samples were analysed for the concentration of food particles in the same way as for the fine mesh Bongo samples. Counts of organisms from the LHPR samples were standardised to numbers in $2 \mathrm{~m}$ depth strata to enable comparison between hauls.

Data analysis. The feeding incidence of the anchovy larval population was taken as the proportion of specimens containing at least 1 food particle, and the feeding intensity as the mean number of food particles in the gut contents of feeding larvae. Data were tested for normality using the Kolmogorov-Smirnov test and for homoscedasticity using Levene's test. Appropriate transformations were applied to non-normal and heteroscedastic data. Comparisons of feeding and food availability between Bongo grids were carried out using $t$-tests; where appropriate, the Mann-Whitney $U$-test was used as an alternative. The mean number and weight of food items in the guts of larvae of different lengths were compared by ANOVA and, where appropriate, the Kruskal-Wallis test. Because LHPR samples within hauls are not independent, data among depths within hauls were pooled for comparison. The relationships between food concentration and depth, the proportion of larvae containing food by depth and food concentration, and mean number of food items in the guts with depth and food concentration were tested by linear regression. Diet selectivity was assessed using the natural log transformation (ln) of the Odds Ratio method (Gabriel 1978, Hillgruber et al. 1995). This selectivity index is symmetrically distributed around a mean of zero and ranges from zero to $+\infty$ or $-\infty$ in cases of positive and negative selection, and the significance can be tested statistically.

\section{RESULTS}

\section{Meteorology and hydrography}

In the $2 \mathrm{wk}$ prior to the commencement of the cruise on 16 June 1996, meteorological conditions were stable, with high atmospheric pressure resulting in low winds and a progressive increase in air and sea surface temperature. Weather conditions remained relatively stable during the first Bongo grid (16 to 18 June), with warm surface water $\left(>24^{\circ} \mathrm{C}\right)$ over much of the sampling area. Low salinity water, originating from the River $\mathrm{Po}$, extended eastwards across the sampling area, with values from $<30$ at the coast to $>36$ farther offshore. The combined effects of high surface temperature and low salinity gave relatively high stratification values over much of the sampled area $(0$ to $20 \mathrm{~m}$ $\Delta \sigma_{1}>3 \mathrm{~kg} \mathrm{~m}^{-3}$ ), with highest values adjacent to the Po outflow area ( 0 to $20 \mathrm{~m} \Delta \sigma_{1}>7 \mathrm{~kg} \mathrm{~m}^{-3}$ ).

In the period 19 to 23 June, immediately following the first Bongo grid, the weather over the northern Adriatic was dominated by a series of depressions and associated fronts with high winds ( 20 to 30 knots) and rough seas. Unsettled weather continued for much of the period between the 2 grids, and markedly changed environmental conditions were recorded on the second Bongo grid (2 to 4 July), which was carried out during a break in the weather. Surface temperatures were lower $\left(>22^{\circ} \mathrm{C}\right)$ and more uniform throughout the sampled area than on the first grid. Despite the increased wind mixing the pattern of surface salinity was similar to that of the first grid, but with the areas of lowest salinity $(<32)$ more immediately localised around the Po outflow, reflecting the increased river run-off associated with precipitation during the period of poor 
weather. Stratification was lower than on the first grid, but still appreciable over much of the survey area ( 0 to $20 \mathrm{~m} \Delta \sigma_{1}>2 \mathrm{~kg} \mathrm{~m}^{-3}$ ). Several days of unsettled weather followed the second Bongo grid, with conditions gradually improving until the end of sampling on 12 July,

\section{Diurnal feeding pattern}

Clupeoid larvae are particularly susceptible to evacuation (regurgitation or defaecation) of their gut contents during sampling and preservation (Arthur 1976). Consequently, while examination of gut contents will indicate the number of larvae containing food and the range of species consumed, it may not provide an accurate quantitative measure of food intake. Of the total anchovy larvae (2.4 to $10.9 \mathrm{~mm}$ in length) examined from both Bongo and LHPR sampling, 889 contained some food remains, but in only 2 larvae was there any food in the fore-gut. In all other specimens the food was in the mid-and hind-guts.

No larvae containing food were sampled from the Bongo grids between 21:34 and 04:37 h (Fig 2). These
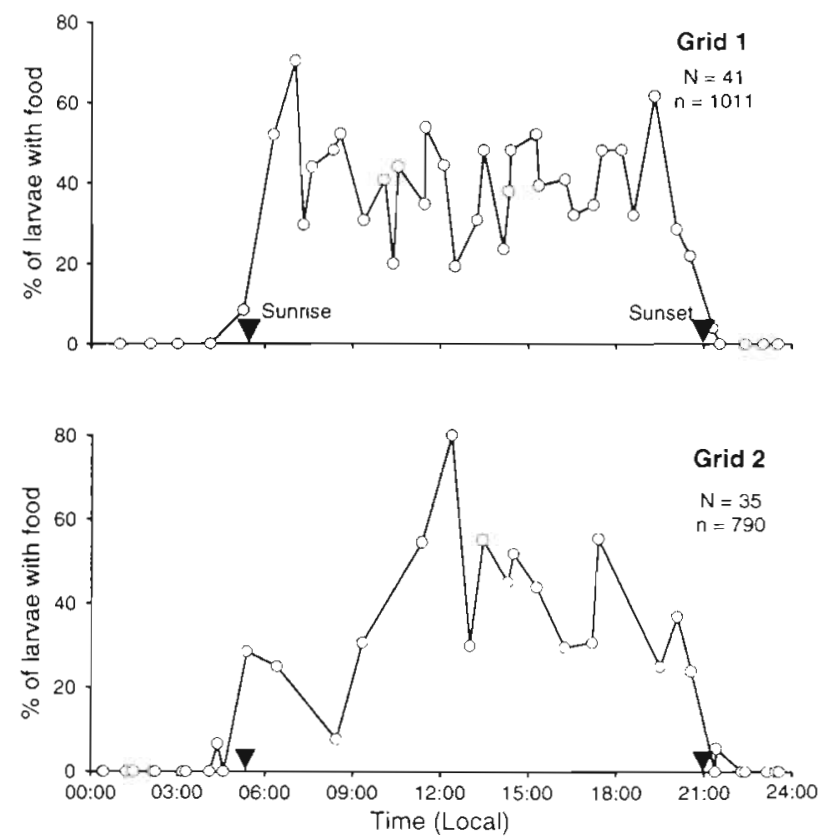

Fig. 2. Engraulis encrasicolus. Diurnal feeding incidence of anchovy larvae sampled from the 2 Bongo grids (Grid 1, 16 to 18 June; Grid 2, 2 to 4 July) plotted as the percentage of larvae with food in their guts for samples containing $>10$ larvae. Times of sunrise and sunset are indicated. $N=$ total number of samples, $n=$ total number of larvae examined

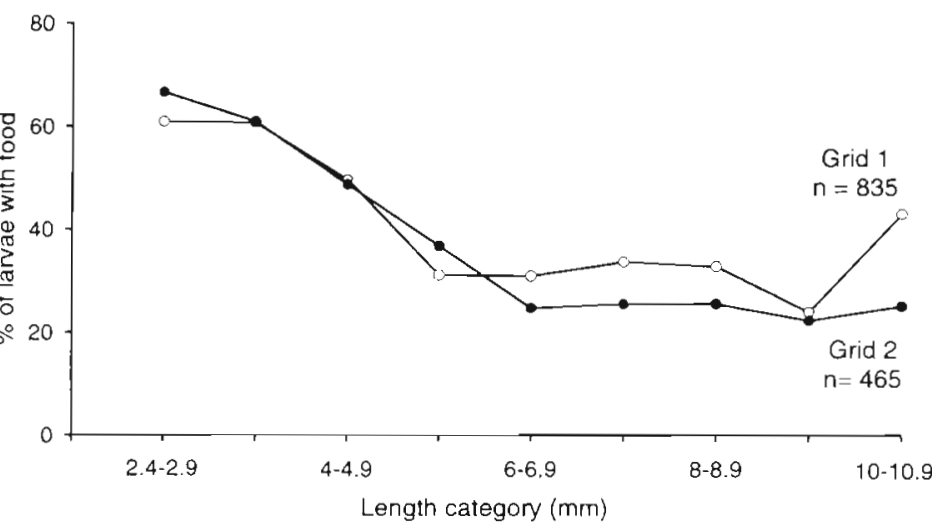

Fig. 3. Engraulis encrasicolus. Percentage incidence of anchovy larvae containing food in relation to larval length sampled on the 2 Bongo grids, based on day samples containing $>10$ larvae. $\mathrm{n}=$ total number of larvae on which the observations are based

times corresponded closely to sunset and sunrise times of $\sim 21: 00$ and $\sim 05: 30 \mathrm{~h}$ respectively. Although there was agreement between the 2 grids in the timing of the larval feeding period, there was considerable variability in the percentage of larvae containing food at different times of the day, with no clear pattern being evident. Overall there was no significant difference between the 2 grids in the percentage of larvae containing food during daylight hours (Grid 1, $39.7 \pm$ $2.37 \%$ and Grid 2, $38.5 \pm 4.16 \%$; Mann-Whitney $U=$ $294, \mathrm{df}=47, \mathrm{p}=0.644$ )

\section{Feeding incidence and intensity in relation to length}

Considering samples taken during the day, feeding incidence decreased with increasing size of larvae to larval lengths of 5 to 5.9 and 6 to $6.9 \mathrm{~mm}$ on Bongo Grids 1 and 2, respectively (Fig. 3). Feeding incidence was then at a more constant level on both grids, although there was an increase on Grid 1 for larvae at 10 to $10.9 \mathrm{~mm}$ in length.

The maximum number of food organisms found in an individual larvae was 17 in a larva of $5.1 \mathrm{~mm}$ in length; otherwise the gut contents comprised mostly between 2 and 10 organisms, with a mean of between 1 and 4 organisms per larva containing food (Fig. 4a). The feeding intensity per larva containing food was not significantly different between the different larval length categories (ANOVA, $F_{8.493}=1.16, p=0.320$ ), but was significantly different between grids ( $t$-test, $t_{500}=3.26$, $\mathrm{p}=0.001$ ). The mean number of organisms per larva was $1.96( \pm 0.089)$ on Grid 1 and $29 \%$ higher at 2.53 ( \pm 0.167 ) on Grid 2.

As an indication of changes in the weight of gut contents in relation to larval length, numbers of food 

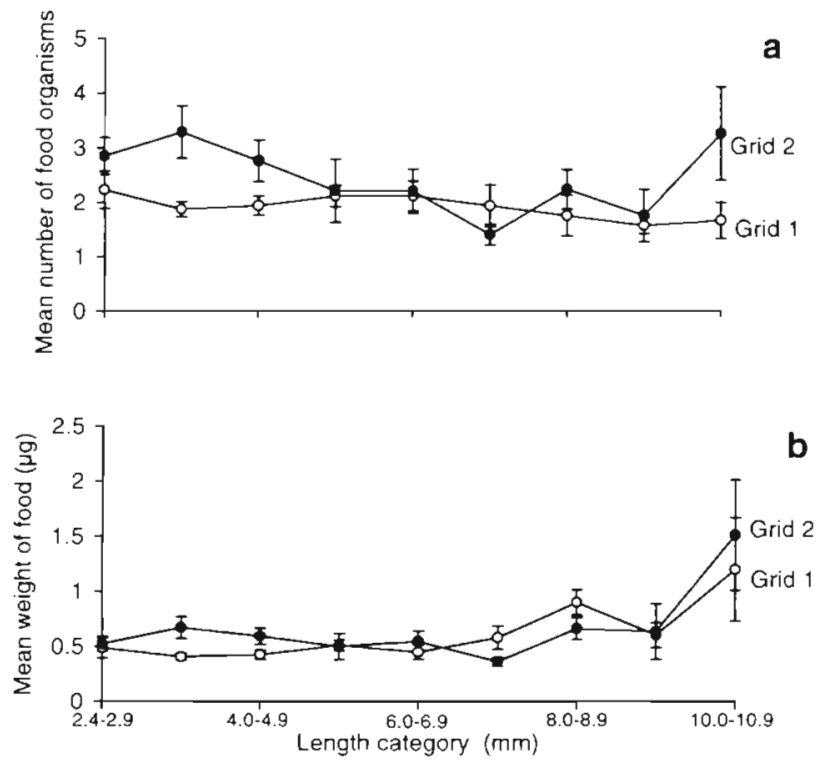

Fig. 4. Engraulis encrasicolus. Gut contents per anchovy larva containing food sampled on the 2 Bongo grids, plotted by larval length as (a) mean number and (b) mean dry weight. Error bars show $\pm 1 \mathrm{SE}$

organisms were converted to dry weight (Table 2, Fig. 4b). In both grids the mean weight of food in the guts remained relatively unchanged at around $0.5 \mu \mathrm{g}$ per larva containing food, up to a larval length of $7.9 \mathrm{~mm}$, and then increased in the larger larvae. The mean weight of food organisms per larva was significantly different between larval length categories (ANOVA, $F_{8,471}=5.86, p<0.001$ ) but did not differ significantly between grids ( $t$-test, $t_{478}=1.38, \mathrm{p}=0.167$ ) . The mean weight of gut contents of larvae containing food was $0.52( \pm 0.025) \mu \mathrm{g}$ on Grid 1 and $12 \%$ higher at $0.58( \pm 0.037) \mu \mathrm{g}$ on Grid 2 .
Table 4. Engraulis encrasicolus. Diet of anchovy larvae 2.4 to $10.9 \mathrm{~mm}$ in length, as the percentage feeding incidence on each food category, by feeding larvae, on each Bongo grid + : values $<0.5 \%$

Food organisms Grid $1(\%)$ Grid $2(\%)$

Copepod eggs and nauplii

Copepod eggs $73 \mu \mathrm{m}$ in diameter 11

Calanus spp. eggs $183 \mu \mathrm{m}$ in diameter 3

Calanoid nauplii

Cyclopoid nauplii

Harpacticoid nauplii

Copepod copepodites

Calanus spp.

Para/Pseudo/Clausocalanus spp.

Acartia spp.

Centropages spp.

Calanoid copepod remains

Oithona spp

Oncaea spp.

Corycaeus spp.

Unidentified cyclopoid copepod

Unjdentified harpacticoid copepod

Other organisms

Cladoceran remains

Lamellibranch larvae

Larvacea

Tintinnids

Unidentified remains

4

9

1

15

61

1

9

1

21

1

20

$-$

$-$

$+$

$+$

$-$

3

1

$\begin{array}{rr}- & 1 \\ 2 & 13\end{array}$

\section{Size of food}

There was a progressive increase in the maximum size of food organisms ingested with increase in larval length, but at the same time smaller organisms were still taken (Fig. 5). The smallest sized organism identified in the gut contents of the anchovy larvae was a tintinnid of $27 \mu \mathrm{m}$ width and the largest a copepod copepodite of $275 \mu \mathrm{m}$ cephalothorax width.

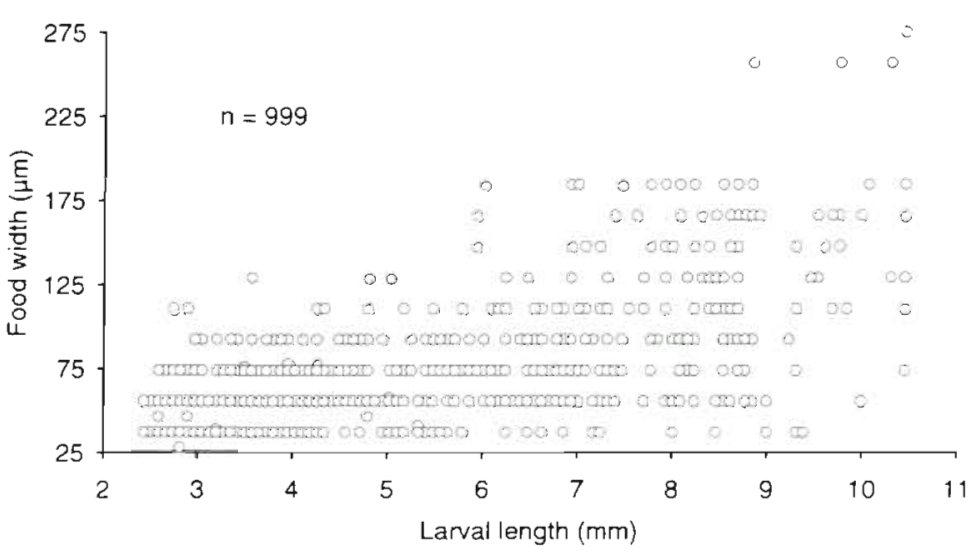

Fig. 5. Engraulis encrasicolus. Widths of individual food items taken by anchovy larvae from combined samples of the 2 Bongo grids. $n=$ number of organisms measured

\section{Dietary composition}

The diet of anchovy larvae taken in the Bongo sampling was predominantly the developmental stages of copepods, including eggs, nauplii and copepodite stages (Table 4). Copepod nauplii were the most numerous component of the diet. Some of the more characteristic nauplii, such as the calanoid Temora spp. and the harpacticoid Microsetella spp., could be identified in the gut contents even when well digested. However, the other nauplii were potentially from a wide range of species and could not be routinely identified with certainty. Most of the harpacticoid copepod 
Table 5. Mean concentration (no. $\mathrm{l}^{-1}$ ) of the preferred food organisms of anchovy larvae 2.4 to $10.9 \mathrm{~mm}$ in length taken in the $53 \mu \mathrm{m}$ samples on the 2 Bongo grids

\begin{tabular}{|c|c|c|c|c|}
\hline \multirow{2}{*}{ Organisms } & \multicolumn{4}{|c|}{ Mean concentration $(95 \% \mathrm{CI})$} \\
\hline & Grid 1 & Grid 2 & $t_{1,40}$ & $\mathrm{p}$ \\
\hline Copepod eggs $(73 \mu \mathrm{m}$ & n) $\begin{array}{c}8.1 \\
(5.9-11.2)\end{array}$ & $\begin{array}{c}2.2 \\
(1.7-2.7)\end{array}$ & $5.49^{\mathrm{d}}$ & $<0.001$ \\
\hline Calanoid nauplii & $\begin{array}{c}22.2 \\
(17.1-29.0)\end{array}$ & $\begin{array}{c}10.3 \\
(8.1-13.3)\end{array}$ & $6.37^{\mathrm{d}}$ & $<0.001$ \\
\hline Cyclopoid nauplii & $\begin{array}{c}33.1 \\
(23.2-43.0)\end{array}$ & $\begin{array}{c}28.4 \\
(17.7-39.1)\end{array}$ & 4.69 & 0.327 \\
\hline Harpacticoid nauplii & $\begin{array}{c}1.4 \\
(0.9-1.9)\end{array}$ & $\begin{array}{c}1.2 \\
(0.7-1.7)\end{array}$ & 0.70 & 0.487 \\
\hline Oithona spp. & $\begin{array}{c}25.7 \\
(20.0-33.0)\end{array}$ & $\begin{array}{c}12.3 \\
(9.9-15.4)\end{array}$ & $5.97^{\circ}$ & $<0.001$ \\
\hline Other copepods & $\begin{array}{c}19.0 \\
(15.2-23.7)\end{array}$ & $\begin{array}{c}7.4 \\
(6.3-8.7)\end{array}$ & $8.11^{\mathrm{a}}$ & $<0.001$ \\
\hline Total organisms & $\begin{array}{c}110.1 \\
(82.8-137.4)\end{array}$ & $\begin{array}{c}64.5 \\
(45.9-83.1)\end{array}$ & 2.74 & 0.007 \\
\hline \multicolumn{5}{|c|}{ "Data were log transformed for statistical analysis } \\
\hline
\end{tabular}

nauplii were probably of non-pelagic species, since, apart from Microsetella spp., few harpacticoid copepods were taken in the plankton samples. The copepod eggs $73 \mu \mathrm{m}$ in diameter were possibly Acartia or Temora spp. Only in larvae from the LHPR samples were the additional food items, these being the dinoflagellate Peridinium spp. and pollen grains, found in low numbers. Most of the copepod eggs, lamellibranch larvae and Peridinium spp. showed little signs of digestion, while other organisms were digested to varying degrees.

\section{Diet in relation to food availability}

There was a clear difference in the percentage incidence of different food organisms in the diet of feeding anchovy larvae between the 2 Bongo grids (Table 4). In Grid 1, calanoid and cyclopoid nauplii were of similar importance in the diet, while harpacticoid nauplii were rarely taken. In Grid 2, feeding incidence on total copepod eggs, calanoid nauplii and copepods other than Oithona spp. was reduced compared with Grid 1, while it increased for cyclopoid nauplii, harpacticoid nauplii and Oithona spp.

When species analysis of all $53 \mu \mathrm{m}$ Bongo samples, taken at the same time as the $280 \mu \mathrm{m}$ samples for anchovy larvae (Table 1), were compared between the 2 Bongo grids, a change in the abundance of the preferred food organisms in the plankton was noted (Table 5). This change was similar to the dietary changes of the anchovy larvae observed between the grids. Between Grid 1 and Grid 2 there was a reduction of $73 \%$ in mean concentration of copepod eggs, a $54 \%$ reduction in calanoid nauplii and a $61 \%$ reduction in other copepods. However, contrary to the increase shown in the diet of anchovy larvae, there was a $52 \%$ reduction in Oithona spp. in the plankton. These changes were all significantly different ( $t$-test, $p<0.001)$. Numbers of cyclopoid and harpacticoid nauplii were not significantly different between the 2 grids ( $p>0.05$ ). The mean overall concentration of the preferred food organisms was significantly reduced by $41 \%$ in Grid 2 compared to Grid $1(p=0.007)$.

\section{Changes in the composition of diet with larval length}

Copepod eggs and nauplii were taken by a wide size range of larvae, both of these dietary components diminishing in importance as the dietary range broadened with increasing larval length (Fig. 6). With increase in length, larvae took progressively larger food items, first the small cyclopoid copepod Oithona spp. and then other larger copepod copepodites. The most apparent difference between the 2 Bongo grids was the shift to larger larvae feeding on Oithona spp. between Grids 1 and 2 .

\section{Vertical distribution of anchovy larvae and zooplankton}

Six LHPR hauls (Table 3) had sufficient larvae to compare the vertical distributions of larvae and potential food organisms (Fig. 7). The plots are restricted to data in the upper $18 \mathrm{~m}$ of the water column since this is the depth range in which most larvae occurred and was a common depth range sampled on all LHPR hauls.

LHPR Haul 1 (21 June) was taken after the first Bongo grid, when stable conditions had just given way to periods of strong wind mixing. Hauls 17, 19, 22 and $23(7,9,10$ and 10 July, respectively) were taken after the second Bongo grid during a period of gradually improving weather. Haul 26 (11 July) was taken during very settled conditions. On only 3 hauls (Hauls 1, 17 and 26) was there pronounced temperature structuring (Fig. 7), but with near isothermal conditions in the top $10 \mathrm{~m}$ of the water column. Because all LHPR hauls were taken during or closely following periods of variable wind mixing, and because the inertial response of larval feeding is not known, a direct comparison 

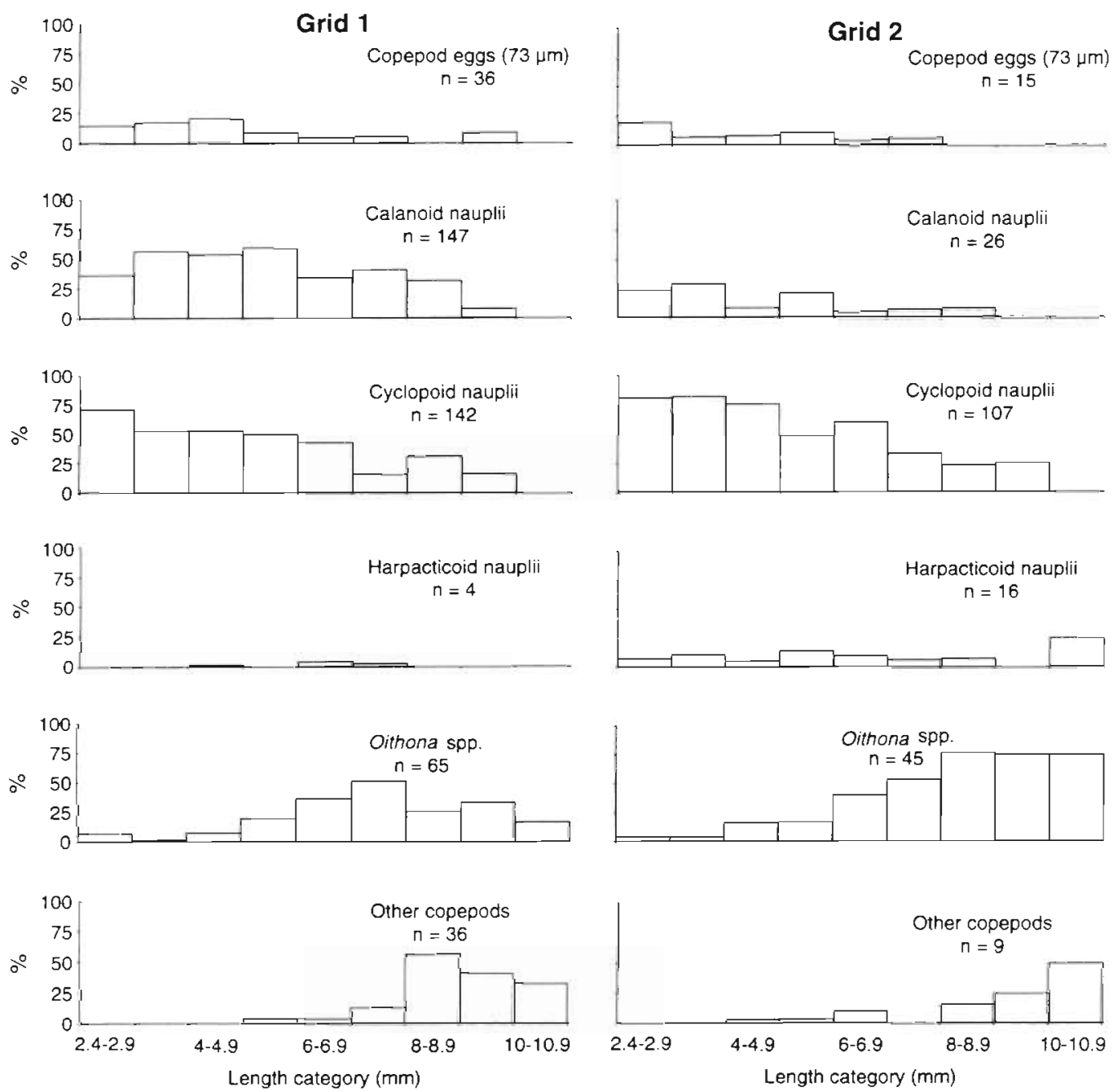

Fig. 6. Engraulis encrasicolus. Diet of anchovy larvae plotted as percentage distribution of the principal food items in each larval length category for the 2 Bongo grids. $n=$ number of food items on which the distributions are based

between feeding and hydrographic conditions at the actual time of sampling was not considered valid. Analysis was restricted to larvae within the 2.4 to $6.9 \mathrm{~mm}$ length category, this being the size range which represented $86 \%$ of all larvae sampled on the LHPR hauls. This length category of larvae had a uniformly restricted diet of copepod eggs, copepod nauplii and copepodites of Oithona spp., with these items numerically comprising $96 \%$ of all food organisms taken.

Excluding LHPR Haul 17, larval anchovy concentrations tended to be relatively low in the upper $2 \mathrm{~m}$ of the water column and either highest just below this, decreasing in numbers with depth, or more evenly distributed throughout the water column. The concentration of preferred food items tended to be lower in the top $2 \mathrm{~m}$ of the water column than at greater depths (Fig. 7). Highest total concentrations of food items were mainly located between depths of 3 and $10 \mathrm{~m}$, varying in this depth zone between 34 and 135 organisms $l^{-1}$ on Hauls 1, 17 and 23, and at lower levels between 22 and 44 organisms $l^{-1}$ on Hauls 19 and 22. On Haul 26, stratification of food organisms was most extreme, with concentrations varying between 18 and 188 organisms $\mathrm{1}^{-1}$. Calanoid nauplii predominated over cyclopoid nauplii in Haul 1 but not in the other hauls. It is significant that LHPR Haul 1 was taken early in the cruise (21 June), before the reduction in numbers of calanoid nauplii observed in the $53 \mu \mathrm{m}$ Bongo samples of the second grid ( 2 to 4 July).

Of the less important food items for anchovy larvae 2.4 to $6.9 \mathrm{~mm}$ in length, copepod copepodites were fairly evenly distributed through the water column, with numbers varying considerably between hauls. Lamellibranch larvae occurred in high numbers in most of the hauls, in concentrations up to $157 \mathrm{1}^{-1}$. Peri- 


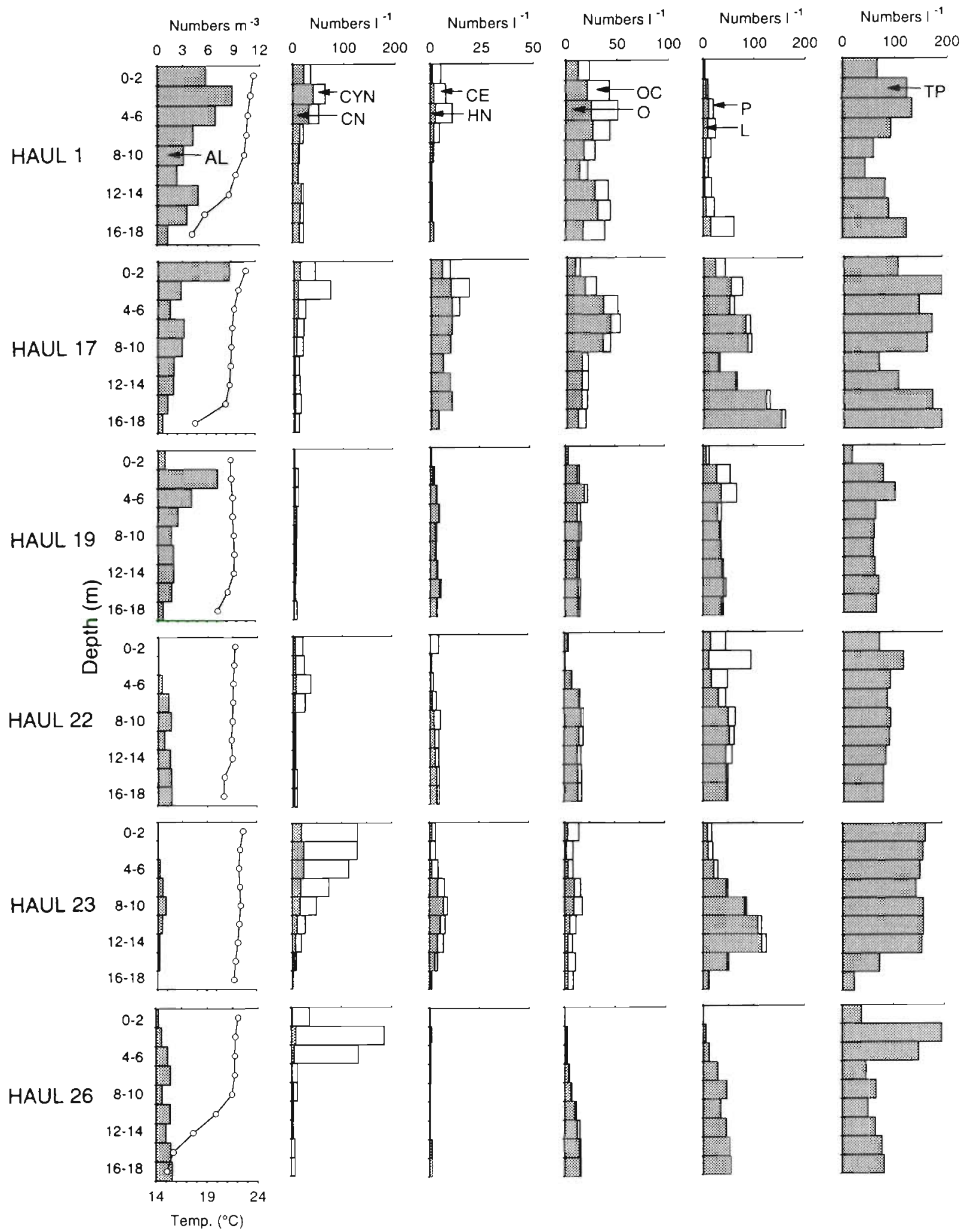

Fig. 7. Vertical distribution of potential food items for anchovy larvae (2.4 to $6.9 \mathrm{~mm}$ in length), from $53 \mu \mathrm{m}$ mesh LHPR samples for the 6 hauls on which there were adequate numbers of anchovy larvae. Vertical distribution of anchovy larvae from the $200 \mu \mathrm{m}$ mesh LHPR samples on the same hauls and temperature structure of the water column are also shown. AL: anchovy larvae; CYN: cyclopoid nauplii; CN: calanoid nauplii; CE: copepod eggs $(73 \mu \mathrm{m})_{i} \mathrm{HN}$ : harpacticoid nauplii; OC: other copepods; O: Oithona spp.; P: Peridinium spp.; L: lamellibranch larvae; TP: total potential food organisms 
dinium spp. were found throughout the water column but tended to be present in highest concentrations, up to $85 \mathrm{l}^{-1}$, within the upper $10 \mathrm{~m}$.

Comparisons between hauls of the highest concentrations of total potential food organisms in the individual $2 \mathrm{~m}$ depth intervals showed a variation of $18 \mathrm{I}^{-1}$ (LHPR Haul 19) and $200 \mathrm{l}^{-1}$ (LHPR Haul 17). The overall vertical distribution of food items was in most cases relatively uniform and showed no clear correspondence with temperature structure.

\section{Changes in feeding success in relation to depth sampled and food concentration}

There were insufficient numbers of anchovy larvae on any individual LHPR haul (Table 3) to permit a within-haul comparison of feeding success and concentration of the preferred food organisms (copepod nauplii, copepod eggs and Oithona spp.) by depth. For this analysis it was therefore necessary to pool the data from samples with $>10$ anchovy larvae per sample for the 6 LHPR hauls. This provided 28 samples with 797 larvae for statistical analysis.
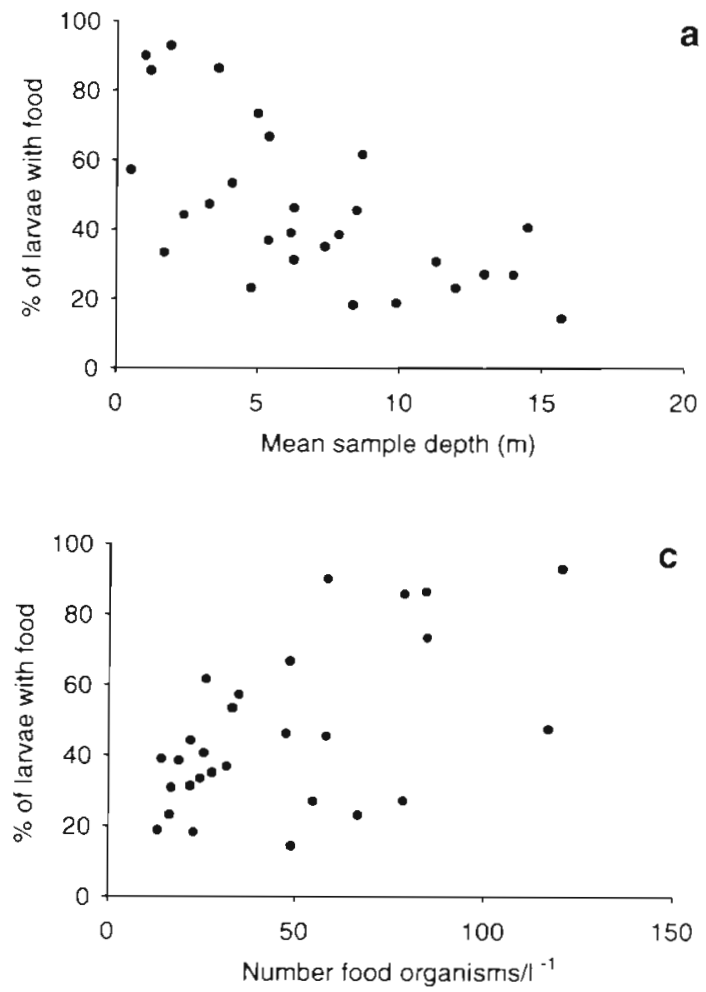

For these combined hauls/samples, food concentration did not vary significantly with depth between the surface and $18 \mathrm{~m}$ depth $\left(\mathrm{r}^{2}=9.4 \%, F_{1,26}=2.70, \mathrm{p}=\right.$ 0.112 ), these 2 variables being subsequently treated as independent. However, there were significant negative relationships between depth and both the percentage of larvae containing food $\left(\mathrm{r}^{2}=40.4 \%, F_{126}=17.62\right.$, $\mathrm{p}<0.001$; Fig. 8a) and the mean number of food items in the gut contents $\left(\mathrm{r}^{2}=16.2 \%, F_{1,26}=5.04, \mathrm{p}=0.033\right.$; Fig. 8b). There were also significant positive linear relationships between food concentration and the percentage of larvae with food $\left(\mathrm{r}^{2}=31.5 \%, F_{1,26}=11.94\right.$, $\mathrm{p}=0.002_{i}$ Fig. $8 \mathrm{c}$ ) and the mean number of food items in the gut contents of larvae $\left(\mathrm{r}^{2}=29.2 \%, F_{1,26}=10.71\right.$, $p=0.003$; Fig. 8d). A multiple regression of percentage of larvae with food using larval depth and food concentration as independent variables yielded an $r^{2}$ of $55.2 \%\left(F_{2,25}=15.39, \mathrm{p}<0.001\right)$ and takes the form:

arcsine(proportion of larvae feeding) $=0.12+$ $0.42 \log$ food concentration (items ${ }^{-1}$ ) $-0.40 \log$ depth (m)

There was a possible interaction among variables (Lack of Fit Test, $p=0.007$ ). However, the overall significance of the multiple regression remains valid.
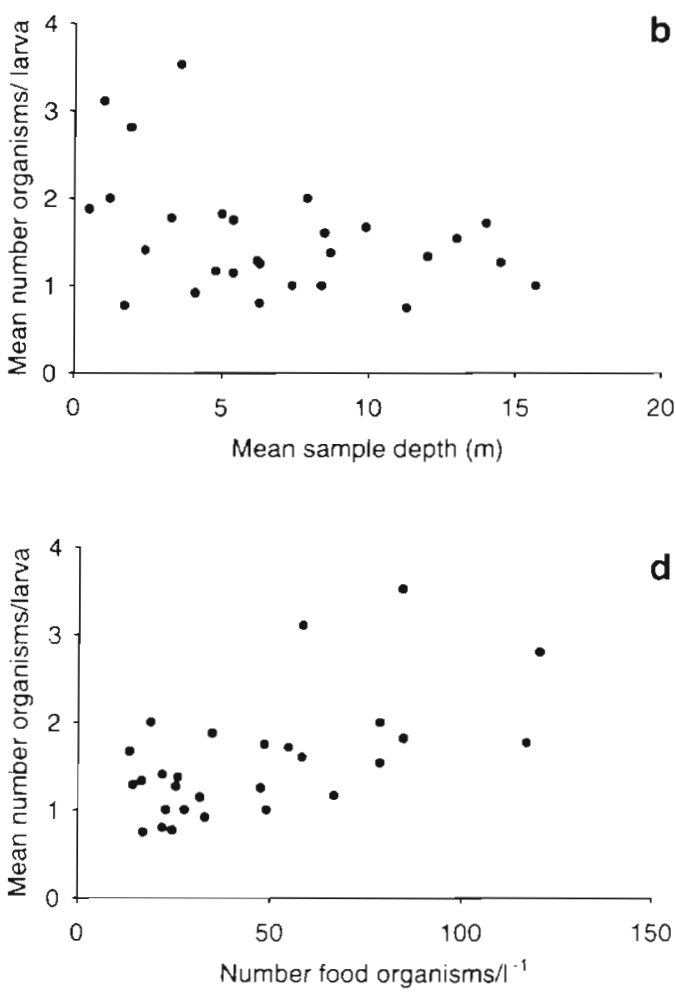

Fig. 8. Engraulis encrasicolus. Relationship on the 6 LHPR hauls (Table 3) between (a) sampling depth and percentage of anchovy larvae containing food organisms. (b) sampling depth and mean number of food organisms per feeding larva, (c) ambient food concentration and percentage of larvae containing food items, and (d) ambient food concentration and mean number of food organisms per feeding larva. Data for all plots are for larvae 2.4 to $6.9 \mathrm{~mm}$ in length from samples on the LHPR hauls containing $>10$ larvae 
Table 6. Engraulis encrasicolus. Percentage occurrence of the preferred food organisms in the gut contents of anchovy larvae 2.4 to $6.9 \mathrm{~mm}$ in length and their percentage occurrence over the corresponding depths in the water column in the $53 \mu \mathrm{m}$ mesh samples from the same LHPR hauls. Results of the Odds Ratio selectivity analysis $( \pm 1 \mathrm{SE}$ ) are also shown where there were comparative data: $p \leq 0.05, \cdots p \leq 0.01, \cdots p \leq 0.001$

\begin{tabular}{|c|c|c|c|c|c|c|c|c|c|c|}
\hline \multicolumn{11}{|c|}{ Prey percentages } \\
\hline \multirow[t]{2}{*}{ Haul no. } & \multicolumn{2}{|c|}{ Calanoid nauplii } & \multicolumn{2}{|c|}{ Cyclopoid nauplii } & \multicolumn{2}{|c|}{ Harpacticoid nauplii } & \multicolumn{2}{|c|}{ Copepod eggs (73 $\mu \mathrm{m})$} & \multicolumn{2}{|c|}{ Oithona spp. } \\
\hline & Diet & $\begin{array}{l}\text { Water } \\
\text { column }\end{array}$ & Diet & $\begin{array}{l}\text { Water } \\
\text { column }\end{array}$ & Diet & $\begin{array}{l}\text { Water } \\
\text { column }\end{array}$ & Diet & $\begin{array}{l}\text { Water } \\
\text { column }\end{array}$ & Diet & $\begin{array}{l}\text { Water } \\
\text { column }\end{array}$ \\
\hline 1 & 40 & 34 & 52 & 17 & 1 & 2 & 3 & 5 & 3 & 41 \\
\hline 17 & 12 & 14 & 83 & 40 & 1 & 12 & 3 & 7 & 1 & 27 \\
\hline 19 & 25 & 11 & 58 & 22 & - & 10 & 6 & 2 & 11 & 54 \\
\hline 22 & 21 & 9 & 64 & 35 & - & 4 & 7 & 8 & 7 & 44 \\
\hline 23 & 56 & 26 & 19 & 42 & - & 14 & 6 & 3 & 19 & 15 \\
\hline 26 & 22 & 8 & 59 & 64 & 3 & 2 & 1 & 2 & 14 & 24 \\
\hline $\begin{array}{l}\text { All hauls } \\
\text { combined }\end{array}$ & 29 & 17 & 56 & 37 & 1 & 7 & 4 & 5 & 9 & 34 \\
\hline \multicolumn{11}{|c|}{ In of Odds Ratio } \\
\hline Haul no. & \multicolumn{2}{|c|}{ Calanoid nauplii } & \multicolumn{2}{|c|}{ Cyclopoid nauplii } & \multicolumn{2}{|c|}{ Harpacticoid nauplii } & \multicolumn{2}{|c|}{ Copepod eggs $(73 \mu \mathrm{m})$} & \multicolumn{2}{|c|}{ Oithona spp. } \\
\hline 1 & 0.27 & $(0.17)$ & $1.65^{\circ}$ & $\cdot\{0.18\}$ & -0.78 & $(0.76)$ & -0.56 & $(0.45)$ & $-3.07^{\circ}$ & $\cdot(0.42)$ \\
\hline 17 & -0.14 & $(0.23)$ & $2.02^{*}$ & $\cdot(0.19)$ & $-2.76^{\circ}$ & $\cdot(0.62)$ & $-0.89^{\circ}$ & $(0.39)$ & $-4.07^{\circ}$ & $\cdot(0.71)$ \\
\hline 19 & $0.94 \cdots$ & $(0.36)$ & $1.58^{\circ}$ & - $(0.29)$ & - & & 0.98 & $(0.69)$ & $-2.28^{\circ}$ & $\cdot(0.36)$ \\
\hline 22 & 1.05 & $(0.67)$ & $1.20^{\circ}$ & $(0.51)$ & - & & -0.15 & $(0.94)$ & $-2.32^{\circ}$ & $(0.88)$ \\
\hline 23 & $1.27^{\circ}$ & $(0.59)$ & -1.15 & $(0.69)$ & - & & 0.79 & $(1.29)$ & 0.29 & $(0.74)$ \\
\hline 26 & $1.23^{\circ}$ & $(0.35)$ & -0.21 & $(0.27)$ & 0.30 & $(0.78)$ & -0.49 & $(1.28)$ & -0.64 & $(0.36)$ \\
\hline $\begin{array}{l}\text { All hauls } \\
\text { combined }\end{array}$ & $0.71 \cdots$ & $\cdot(0.11)$ & $0.78^{\circ}$ & $\cdot(0.09)$ & $-2.25^{\prime}$ & $\cdot(0.42)$ & -0.03 & $(0.22)$ & $-1.64^{\circ}$ & $\cdot(0.14)$ \\
\hline
\end{tabular}

Thus, most of the variability in the proportion of larvae with food can be explained by variation in larval depth and food concentration.

\section{Food selection}

Based on the vertical distribution LHPR data, there were no significant differences between the relative abundance of food organisms in the gut contents of anchovy larvae and food concentration at the same depth (Mann-Whitney U-test, $p>0.05$ ). However, considering the preferred prey organisms, anchovy larvae (2.4 to $6.9 \mathrm{~mm}$ in length) significantly selected for calanoid and cyclopoid nauplii and significantly selected against harpacticoid nauplii and Oithona spp. (Table 6). Copepod eggs were present in the larval gut contents in proportion to their concentration in the water column

Although there were inadequate data for statistical analysis, the few occasions when anchovy larvae fed on lamellibranch larvae and Peridinium spp. are of interest. On LHPR Haul 19, 13\% of anchovy larvae with food in their guts were noted to have fed on lamellibranch larvae and $4 \%$ on Peridinium spp., all these anchovy larvae occurring within the top $8 \mathrm{~m}$ of the water column; on this haul there was the lowest concentration of copepod nauplii and some of the highest combined concentrations of lamellibranch larvae and Peridinium spp. in the top $8 \mathrm{~m}$ of all the LHPR hauls (Fig. 7). On LHPR Haul 22, $12 \%$ of anchovy larvae with gut contents were noted as having fed on Peridinium spp., all the larvae occurring within the top $8 \mathrm{~m}$ of the water column; on this haul there was the second lowest concentration of copepod nauplii and the highest concentration of Peridinium spp. in the top $8 \mathrm{~m}$ of all the LHPR hauls.

\section{DISCUSSION}

Brief descriptions of the diet of European anchovy larvae have been given for the northwestern Adriatic Sea by Coombs et al. (1997), for the Croatian coastal region of the mid-Adriatic by Regner (1971), from the Black Sea by Pavlovskaja (1961) and from Spanish coastal waters in the northwestern Mediterranean by Tudela \& Palomera (1995). In all of these limited feeding studies the diet was a restricted range of organisms, predominantly the developmental stages of copepods, especially nauplii, similar to the diet of most larval fish (e.g. Last 1980). Ferreira \& Ré (1993) 
described the diet of anchovy from a Portuguese estuary, but the dietary composition ( $>80 \%$ tintinnids) differed considerably from that found in more open sea studies. In the present study, apart from low numbers of Peridinium spp., phytoplankton did not appear to be important in the diet of first feeding anchovy larvae, which has been noted in other studies (Tudela \& Palomera 1995), although Regner (1971) recorded green amorphous material in the guts of the earliest stage larvae. Larvae at all lengths fed on copepod nauplii, and with increase in length and mouth gape also took larger organisms. Larval fish, as they develop, typically show alterations in prey size at a considerably lower rate than their physical capacity allows (Pepin \& Penney 1997). Oithona spp., which are intermediate in size between copepod nauplii and larger copepod species, were an important food item, as they are in the diets of a wide range of larval fish (Last 1980). While only small numbers of copepod eggs, lamellibranch larvae and Peridinium spp. were taken, these are all items which may resist digestion (Conway et al. 1994b) and usually appeared to be undigested. These organisms have good nutritional potential and have been shown to be digested by some larval fish species (e.g. Bainbridge \& McKay 1968, Jenkins 1987).

Larval fish typically have a higher feeding incidence and intensity during the day than at night (Last 1980); this is associated in the majority of cases with a reliance on visual feeding (e.g. Batty 1987). However, for the larvae of most fish species, food is retained in the guts for at least a substantial part of the night (Last 1980). During this period of inactivity they can digest and assimilate food efficiently (Canino \& Bailey 1995). Anchovy larvae are unusual among fish larvae in that their guts were completely emptied within $30 \mathrm{~min}$ of sunset, suggesting a different energetic strategy from the larvae of the majority of other fish species. This apparent rapid passage rate of food should allow a more accurate comparison of the gut contents with the ambient food in the plankton than for other species with slower gut passage rates which may ingest their food over a longer time prior to capture.

In samples taken during the day in the present study, the percentage of anchovy larvae containing food decreased rapidly with increase in larval length up to about 5 to $6.9 \mathrm{~mm}$ in length and then levelled off before increasing again, at least in Grid 1, at a length of 10 to $10.9 \mathrm{~mm}$. This observation is similar to the results of Arthur (1976), who compared the feeding incidence/length relationship of Sardinops sagax and Engraulis mordax with that found in 5 other studies on Engraulis spp. All showed initial decreases in feeding incidence with length, followed by an increase from $12 \mathrm{~mm}$ in length. It is possible that there is either a lack of suitable food for larger larvae, which was not appar- ently the situation in the present study, or that, over this intermediate stage of gut development, clupeoid larvae are particularly susceptible to evacuation of food as a result of sampling trauma.

The effects of food evacuation may also be reflected in the mean number of organisms per anchovy larvae with food in their gut contents. This varied from 1.4 to 3.3 particles per larva, with no evidence of an increase in numbers taken with increasing larval length. The observed number of food organisms in the gut contents of anchovy larvae is typical of most field studies on clupeoids (Conway et al. 1994a, Viñas \& Ramírez 1996). However, Ferreira \& Ré (1993) recorded a higher mean number of food organisms in anchovy larvae, this being a maximum of 8 food items, although these food particles were predominantly small tintinnids.

The LHPR vertical sampling demonstrated that the most abundant length group of anchovy larvae (2.4 to $6.9 \mathrm{~mm}$ ) was distributed mainly in the upper $18 \mathrm{~m}$ of the water column, with highest concentrations between 2 and $10 \mathrm{~m}$ depth. The preferred food organisms for this size group of larvae (copepod eggs, nauplii, and Oithona spp.) were also most concentrated in this depth range, although there was considerable variability in absolute concentration between hauls (18 to $188 \mathrm{l}^{-1}$ ). Apart from results for 1 of the LHPR hauls (Haul 26, which was taken following a period of light winds), potential food was not strongly vertically stratified and would generally have required a significant migration by larvae to move between substantially different food concentrations.

There is evidence from field studies that food availability can directly affect larval feeding success (Anderson 1994, Fortier et al. 1995) and from experimental studies that it can affect growth rate (Gotceitas et al. 1996). In the present study, while the subset of LHPR samples tested statistically showed no significant difference in prey concentration with depth, larval feeding success, as measured both by the proportion of larvae feeding and the number of items in the gut contents, was seen to be independently related both to prey concentration and to the depth at which the larvae were sampled. Prey concentration appeared to affect food intake only at levels below $\sim 50$ food particles $\mathrm{l}^{-1}$ However, even at low food concentrations, larvae were not necessarily subjected to nutritional deprivation, since there remains the balance between food intake, gut passage rate and assimilation efficiency to be considered (Govoni et al. 1986).

The reduction in feeding success with depth is interpreted as not being due to gut evacuation due to differences in time spent in the sampling net, since on all LHPR hauls the surface samples were collected first. It may be related to a reduction in light levels, which can affect larval feeding activity (Batty 1987). 
However, it is surprising that this possible feeding/ depth relationship was observed at such shallow depths $(0$ to $18 \mathrm{~m})$, although light reduction in the highly turbid superficial waters of the northern Adriatic (Justic 1988) might be sufficient to affect feeding performance. Alternatively, it is possible that the larvae without food at depth were larvae in poor condition. Starvation in gadoid larvae results in increased buoyancy due to increasing tissue water content and decreasing protein levels (Frank \& McRuer 1989), so that larvae in poor condition can be found distributed towards the surface. However, when they suffer osmoregulatory failure they tend to become less buoyant and occupy a deeper position in the water column (Sclafani et al. 1997).

Fish larvae do not feed indiscriminately, particular organisms being taken selectively, and co-occurring species can have completely different diets (Last 1980). Lamellibranch larvae and Peridinium spp. were frequently abundant in the plankton, yet were only taken by small larvae ( 2.4 to $3.9 \mathrm{~mm}$ in length) when availability of other food was low and the concentration of lamellibranch larvae and Peridinium spp. was high. Similar selectivity has been noted for cod larvae (Munk 1995), which were less discriminating when food was scarce. Evidence for a high degree of feeding discrimination in fish larvae has been shown by selection of copepod nauplii even at the species level (Hillgruber et al. 1995), possibly due to differential perception by larvae resulting from variations in nauplii swimming behaviour (Paffenhöfer et al. 1996). For anchovy larvae 2.4 to $6.9 \mathrm{~mm}$ in length, calanoid and cyclopoid nauplii were selected in preference to harpacticoid nauplii and Oithona spp. However, motility is not an essential prerequisite for feeding, since copepod eggs which were only present in the plankton in low numbers were taken in the same proportions as they were available.

Following the period of increased wind mixing between the 2 Bongo grids, there was a marked overall change in the plankton in concentration $(41 \%$ reduction) and relative composition of the principal food items of larvae 2.4 to $10.9 \mathrm{~mm}$ in length. It is not known whether these changes were due to advection or to disruption of zooplankton production. Observed changes were clearly reflected in the diet of anchovy larvae; in Grid 2, larvae compensated for reduction in numbers of calanoid nauplii and 'other copepods' by increasing their intake of cyclopoid nauplii and Oithona spp. Dietary flexibility of fish larvae in response to differing species composition of available food has been detected in other situations, for example over several months in an evolving plankton community (Last 1980), in adjacent water masses within and outwith a river plume (Govoni \& Chester 1990) and where there are interannual changes in food composition (Anderson 1994).

Strong wind mixing is generally considered to lead to increased mortality in fish larvae (Lasker 1975 , Peterman \& Bradford 1987), possibly as a result of poor feeding success due to dispersal of food concentrations. In the present study, the vertical distribution of total potential food organisms was reasonably uniform under a range of wind mixing conditions. Despite the lower overall food concentration on the second grid, feeding success was not reduced and the mean number of food organisms taken by anchovy larvae was significantly higher. However, the increase in food intake may not represent enhanced feeding success, because the estimated weight of food was not significantly higher. This was due to replacement of calanoid nauplii in the diet by greater numbers of smaller, lighter cyclopoid nauplii. There may even have been a reduction in nutritional quality due to consumption of greater numbers of these smaller nauplii, since on a consideration of the ratio of surface area to volume they will have a greater proportion of indigestible exoskeleton. Additionally, there may have been a higher energetic expenditure in the capture of greater numbers of smaller prey. Energetically, there was probably little difference in feeding success before and after the period of increased wind mixing and thus no evidence, under the particular environmental conditions studied, that the substantial changes in food concentrations observed would have modified overall larval mortality.

Acknowledgements. This work forms part of the programme of the Centre for Coastal and Marine Sciences, Plymouth Marine Laboratory (PML), and was funded in part by the Direzione Generale Pesca e Acquicoltura, Ministero delle Risorse Agricole, Alimentari e Forestali, and by the Istituto Centrale per la Ricerca scientifica e tecnologica Applicata al Mare (ICRAM), Rome. We thank the ship's complement of the research vessel N/O 'Thetis' and colleagues from the Plymouth Marine Laboratory and ICRAM Laboratories, Chioggia and Rome, who participated in the programme.

\section{LITERATURE CITED}

Anderson JT (1994) Feeding ecology and condition of larval and pelagic juvenile redfish Sebastes spp. Mar Ecol Prog Ser 104:211-226

Arthur DK (1976) Food and feeding of larvae of three fishes occurring in the California Current, Sardinops sagax. Engraulis mordax and Trachurus symmetricus. Fish Bull US 74:517-530

Bailey KM, Houde ED (1989) Predation on eggs and larvae of marine fishes and the recruitment problem. Adv Mar Biol 25:1-83

Bainbridge V, McKay BJ (1968) The feeding of cod and redfish larvae. Spec Publs Int Commn NW Atl Fish 7 : 187-218

Batty RS (1987) Effect of light intensity on activity and food- 
searching of larval herring, Clupea harengus: a laboratory study. Mar Biol 94:323-327

Bradford MJ, Cabana G (1997) Interannual variability in stage-specific survival rates and the causes of recruitment variation. In: Chambers RC. Trippel EA (eds) Early life history and recruitment in fish populations. Chapman \& Hall, London, p 469-493

Canino MF, Bailey KM (1995) Gut evacuation of walleye pollock larvae in response to feeding conditions. J Fish Biol 46:389-403

Conway DVP, Coombs SH, Fernández de Puelles ML, Tranter PRG (1994a) Feeding of larval sardine, Sardina pilchardus (Walbaum), off the north coast of Spain. Bol Inst Esp Oceanogr 10:165-175

Conway DVP, McFadzen IRB, Tranter PRG (1994b) Digestion of copepod eggs by larval turbot Scophthalmus maximus and egg viability following gut passage. Mar Ecol Prog Ser 106:303-309

Coombs S, Giovanardi O, Conway D, Manzueto L, Halliday $N$, Barrett C (1997) The distribution of eggs and larvae of anchovy (Engraulis encrasicolus) in relation to hydrography and food availability in the outflow of the river Po. Acta Adriat 38:33-47

Dower JF, Miller TJ, Leggett WC (1997) The role of microscale turbulence in the feeding ecology of larval fish. Adv Mar Biol 31:169-220

Ferreira PL, Ré P (1993) Feeding of larval anchovy, Engraulis encrasicolus (L.), in the Mira estuary (Portugal). Port Zool 2:25-37

Fortier L, Ponton D, Gilbert M (1995) The match/mismatch hypothesis and the feeding success of fish larvae in icecovered southeastern Hudson Bay. Mar Ecol Prog Ser 120: $11-27$

Fox CJ (1996) Length changes in herring (Clupea harengus) larvae: effects of capture and storage in formaldehyde and alcohol. J Plankton Res 18:483-493

Frank KT, McRuer JK (1989) Nutritional status of field collected haddock (Melanogrammus aeglefinus) larvae from southwestern Nova Scotia: an assessment based on morphometric and vertical distribution data. Can J Fish Aquat Sci 46(Suppl 1):125-133

Gabriel WL (1978) Statistics of selectivity. In: Lipovsky SJ, Simenstad CA (eds) Gutshop '78. Fish food habit studies. Proc 2nd Pacific Northwest Technical Workshop. Washington Sea Grant, Division of Marine Resources, University of Washington $\mathrm{H}-30$, Seattle, p 62-66

Geffen A.J (1996) Effect of experimental manipulation of feeding conditions on the population structure of larval cod (Gadus morhua) and herring (Clupea harengus). Mar Freshw Res 47:291-300

Gotceitas V, Puvanendran V, Leader LL, Brown JA (1996) An experimental investigation of the 'match/mismatch' hypothesis using larval Atlantic cod. Mar Ecol Prog Ser 130:29-37

Govoni JJ, Boehlert GW, Watanabe Y (1986) The physiology of digestion in fish larvae. Environ Biol Fish 16:59-77

Govoni JJ, Chester A.J (1990) Diet composition of larval Leiostomus xanthurus in and about the Mississippi River plume. J Plankton Res 12:819-830

Hay SJ, Evans GT, Gamble JC (1988) Birth, growth and death rates for enclosed populations of calanoid copepods. J Plankton Res 10:431-454

Hillgruber N, Haldorson LJ, Paul AJ (1995) Feeding selectivity of larval walleye pollock Theragra chalcogramma in the oceanic domain of the Bering Sea. Mar Ecol Prog Ser 120:1-10

Jenkins GP (1987) Comparative diets, prey selection, and predatory impact of co-occurring larvae of two flounder species. J Exp Mar Biol Ecol 110:147-170

Justic $D$ (1988) Trend in the transparency of the northern Adriatic Sea 1911-1982. Mar Pollut Bull 19:32-35

Lagadeuc Y, Boulé M, Dodson JJ (1997) Effect of vertical mixing on the vertical distribution of copepods in coastal waters. J Plankton Res 19:1183-1204

Lasker R (1975) Field criteria for survival of anchovy larvae: the relation between inshore chlorophyll maximum layers and successful first feeding. Fish Bull US 73:453-462

Last JM (1980) The food of twenty species of fish larvae in the west-central North Sea. Fish Res Tech Rep No. 60, MAFF Directorate of Fish Res, Lowestoft

Leggett WC, Deblois E (1994) Recruitment in marine fishes: is it regulated by starvation and predation in the egg and larval stages? Neth J Sea Res 32:119-134

Mackenzie BR, Leggett WC, Peters RH (1990) Estimating larval fish ingestion rates: can laboratory derived values be reliably extrapolated to the wild? Mar Ecol Prog Ser 67 209-225

Maillet GL, Checkley DM (1991) Storm-related variation in the growth rate of otoliths of larval Atlantic menhaden Brevoortic tyrannus: a time series analysis of biological and physical variables and implications for larval growth and mortality. Mar Ecol Prog Ser 79:1-16

McFadzen IRB, Franceschini G (1997) The nutritional condition of larvae of anchovy (Engraulis encrasicolus) in the outflow of the River Po (Northern Adriatic). Acta Adriat 38: $49-64$

Munk P (1995) Foraging behaviour of larval cod (Gadus morhua) influenced by prey density and hunger. Mar Biol 122:205-212

O'Connell CP (1976) Histological criteria for diagnosing the starving condition in early post yolk sac larvae of the northern anchovy, Engraulis mordax Girard. J Exp Mar Biol Ecol 25:285-312

Paffenhöfer GA, Strickler JR, Lewis KD, Richman S (1996) Motion behavior of nauplii and early copepodid stages of marine planktonic copepods. J Plankton Res 18: 1.699-1715

Pavlovskaja RM (1961) La survie des larves de l'anchois de la mer Noire en fonction de leur alimentation. Rapp Comm Int Mer Médit 16:345-350

Pepin P, Myers RA (1991) Significance of egg and larval size to recruitment variability of temperate marine fish. Can J Fish Aquat Sci 48:1820-1828

Pepin P, Penney RW (1997) Patterns of prey size and taxonomic composition in larval fish: are there general sizedependent models? J Fish Biol 51 (Suppl A):84-100

Peterman RM, Bradford MJ (1987) Wind speed and mortality rate of a marine fish, the northern anchovy (Engraulis mordax\}. Science 235:354-356

Regner S (1971) Feeding of anchovy postlarvae, Engraulis encrasicolus (Linnaeus, 1758), in the Middle Adriatic. Ekologija 6:157-164 (in Serbo-Croatian)

Regner S (1996) Effects of environmental. changes on early stages and reproduction of anchovy in the Adriatic Sea. Sri Mar 60:167-177

Sclafani M, Stirling G, Leggett WC (1997) Osmoregulation, nutritional effects and buoyancy of marine larval fish: a bioassay for assessing density changes during the earliest life-history stages. Mar Biol 129:1-9

Theilacker GH, Bailey KM, Canino MF, Porter SM (1996) Variations in larval walleye pollock feeding and condition: a synthesis. Fish Oceanogr 5(Suppl 1):112-123

Thompson AB, Harrop RT (1991) Feeding dynamics of fish larvae on Copepoda in the western Irish Sea, with partic- 
ular reference to cod Gadus morhua. Mar Ecol Prog Ser 68:213-223

Tudela S, Palomera I (1995) Microzooplancton and feeding of anchovy larvae in northwestern Mediterranean. Rapp Comm Int Mer Médit 34:259

Viñas MD, Ramírez FC (1996) Gut analysis of firstfeeding anchovy larvae from the Patagonian spawning

Editorial responsibility: Otto Kinne (Editor)

Oldendorf/Luhe, Germany areas in relation to food availability. Arch Fish Mar Res 43: $231-256$

Williams R, Collins NR, Conway DVP (1983) The double LHPR system, a high speed micro- and macroplankton sampler. Deep-Sea Res 30:331-342.

Zore-Armanda M, Gačić M (1987) Effects of bura on the circulation in the North Adriatic. Ann Geofis 5b:93-102

Submitted. June 3, 1998; Accepted: August 21, 1998

Proofs received from author(s): November 26, 1998 